\title{
Unemployment and Labor Market in Urban Ethiopia: Trends and Current Conditions
}

\author{
Fitsum Dechasa Kibret \\ Center for Environment and Development, Addis Ababa University, Addis Ababa, Ethiopia \\ Corresponding Author: laryfdk@yahoo.com
}

Copyright (C) 2014 Horizon Research Publishing All rights reserved.

\begin{abstract}
Ethiopia is one of the African countries with the highest rate of urbanization. Such high growth rate of Ethiopian urban centers presents enormous challenges to the nation. One of the developmental challenges facing urban Ethiopia today is unemployment. While there is little improvement in urban unemployment reduction, the overall performance in employment creation remained sluggish. Despite the growth in the labor force, employment growth is inadequate to absorb labor market entrants. The great concern here is, therefore, whether there should be substantial growth in job creation in urban areas to absorb new labor market entrants. This calls for a careful assessment of the current urban unemployment and labor market situation and efforts being done towards employment creation. On this ground, this essay focuses on conceptual, theoretical and policy-relevant description of unemployment and labor market situation in urban Ethiopia. Accordingly, urban unemployment, despite declining trend is still high, the problem being more prevalent among female and youth group. It shows great difference across regional urban level. The review on urban labor market situation of Ethiopia based on ILO KILM shows that urban labor force participation rate and employment rate do not show that much improvement; only about half of the urban labor force is employed as of March 2012. About one third of the total employed individuals were engaged in informal sectors showing the significant role of informal sector in urban Ethiopia as an important part of economic life which tends to absorb a considerable amount of the growing urban labor force. There are different policies and strategies introduced and implemented by the government for employment generations on both the demand and supply side in the public and private sectors. However, the employment creation role of both public and private sectors have been constrained by different factors among others are privatization, tax rate, lack of or inadequate finance/credit and infrastructure/facilities. For these the suggestions made are addressing the poor labor market situation of female; implementing labor-intensive employment creation strategies for the growing young skilled labor force; and arranging access to organized market, credit institution, modern technology, formal training and
\end{abstract}

providing institutional protection for informal sectors.

Keywords Urban Unemployment, Labor Market, Employment Creation

\section{Introduction}

\subsection{Background}

Unemployment is one of the several socio-economic problems prevailing in virtually all countries of the world. It has long been one of the several features of the urban phenomenon in many countries though some countries have suffered the worse rate of unemployment than others [21, 19]. The problem has a serious effect not only on the living standards of the people (negative effects on the psychology, socio-economic and physical well-being) but also on the socio-economic status of a nation [19].

Today, in most of the developing countries the problem of unemployment is a central concern of development; and more recently the discussion has focused on unemployment in urban sectors [24]. Many urban centers in developing countries are challenged by high rates of unemployment. Moreover, despite the huge unemployed labor force, urban centers of these nations experience high rate of rural-to-urban migration, exacerbating the unemployment problem of urban areas [2]. A spatial perspective of Africa's labor market outcomes witness higher rates of unemployment in urban areas than in rural ones [6].

As in many other developing countries, the urban labor market in Ethiopia is typically characterized by huge inefficiency and underdevelopment. Labor supply by far exceeds labor demand and many men and women are looking but unable to find job and stay unemployed (open unemployment) [26]. In urban Ethiopia the labor force grows with an increasing proportion while the opportunity of employment is inadequate to absorb the labor market entrants and thus, unemployment presents a particular challenge. Though there is some improvement the country 
yet faces high joblessness and sluggish job creation in urban areas. The concern is whether there should be substantial growth in job creation in urban areas to absorb new labor market entrants. This calls for a careful study of the current urban unemployment and labor market situation, efforts being done towards employment creation and the challenges towards those efforts. Thus, this paper, although it does not claim to be a comprehensive assessment, intended to make contribution to the existing knowledge of the prior efforts in those issues related to unemployment in urban Ethiopia.

\subsection{Problem Statement}

Although Ethiopia's economy has made some major strides forward at least over the recent past years, the development challenge facing Ethiopia is yet immense [26]. One of the central elements of Ethiopia's developmental challenge is unemployment and the inefficient labor market of urban areas. With an urbanization rate of approximately $4 \%$ per annum, Ethiopia has one of the fastest growing urban populations in Africa [18]. It is estimated that 14 million people, accounting for about $16 \%$ of the total population, are residing in urban areas [4]. Urban population growth is not only the feature of Addis Ababa, the capital, but is also of numerous secondary cities. This high rate of urbanization places Ethiopia's urban centers under great stress, one being unemployment.

Despite some improvements in recent years, a high level of unemployment continues to be a serious social problem and major policy challenge facing urban Ethiopia [12]. While the labor force grows, employment growth is inadequate to absorb labor market entrants. In this context, a much better understanding of urban unemployment and the functioning in urban labor markets, and forwarding key policy implications is of a great importance. That is why the issue, urban unemployment, has become the concern of many academicians, political leaders and other professionals today. However, majority of the researches that have been done so far tends to concentrate on the incidence of unemployment at country level (aggregate of rural and urban) or in specific population categories, usually urban youth or women unemployment $[7,23,3,14]$; others consider unemployment problem in a particular urban area [25], and thus it is quite rare to find recent works that attempt to holistically deal the issue of unemployment at national urban level integrating it with labor market, and efforts and challenges of employment creation.

The argument here is, therefore, that for the better understanding of urban unemployment and for comprehensive actions aimed at improving the problem, it is better to have a look at the current urban unemployment and the labor market situation at national level. Hence, this study tries to give a brief insight into current unemployment situation in urban Ethiopia; the response to it from both demand and supply side of the labor market and challenges related to employment creation. The insights that have been drawn could also contribute to the growing literature on urban unemployment in Ethiopia.

\subsection{Objectives}

The Main Objective of the study is to give insight into the current unemployment and labor market situation in urban Ethiopia.

Specifically the essay intends to:

$\rightarrow$ Identify the factors/challenges that deter employment creation in urban Ethiopia.

$\rightarrow$ Characterize the existing urban labor market situation in Ethiopia.

$\checkmark$ Assess efforts and major interventions that are being done in solving urban unemployment problem in Ethiopia.

\subsection{Methodology}

This essay employed a mix of two approaches with a great weight on critical analysis of secondary data and literature. The first is a discussion on the issue of urban unemployment in Ethiopia. The specific methods employed here include review and analysis of the existing literature/ facts and figures/ on each of the questions of interest- challenges of employment creation and the major intervention being done in solving urban unemployment problem. The essay heavily relies on statistical data of CSA UEUS/Central Statistical Authority Urban Employment Unemployment Survey/of the year 2013. Facts and figures from MoLSA/Ministry of Labor and Social Affairs; MoFED/Ministry of Finance and Economic Development; the existing national employment policies and strategies/NEPS/ and other major intervention tools used in employment creation and policy implementation. However, the paper does not claim for an all encompassing collection of information.

The essay is also supplemented by primary data which is obtained through individual interview of seven individuals (four female and three male). This is not to arrive at conclusion rather simply to see their views and perceptions on unemployment; the available employment opportunities; the interventions of unemployment reduction and the constraints of employment in their specific case. Interviews were conducted in Addis Ababa in the area of Akaki. Interviewees were selected using snowball sampling technique.

The qualitative data generated from interviews was organized and analyzed qualitatively through content analysis. For this purpose, first, the recorded information from the informal discussion was translated from the local language (Amharic) to English. Second, by reading through all of the qualitative data, it was reviewed and organized to develop a general understanding of the data set. Then, through narrative description the result of the entire qualitative data was analyzed and interpreted. In so doing, the information generated from interview is integrated with the analysis of facts and figures from different sources. 


\section{Unemployment: Concepts and Theories}

\subsection{Concepts and Definitions}

By its very nature the concept of unemployment is complex and broad. Thus, for clear understanding of the issue, in this section, an attempt has been made to explain unemployment and related concepts.

Economic activity or productive activity: in this essay, is contextualized as it has been used in CSA UEUS report of 2012. Accordingly, it refers to work which involves the production of goods and/or services for sale or exchange. Production of primary products for own consumption; processing of primary products by the producers themselves; production of other commodities where part of it is sold on the market; own account construction and fixed asset formation; and the practical activities of apprentices are also considered as economic activities. On the other hand, unpaid household chores such as preparing food, cleaning the house, taking care of children; and unpaid community and volunteer services are not considered as economic activities [4].

Based on this standard definition of economic activity urban $^{1}$ population of the country aged ten years and above (working-age population) are classified into currently economically active population and economically inactive population.

Economically active population (labor force): refers to persons who are engaged (employed) or available to be engaged (unemployed) in the economic or productive activities.

Economically inactive population: refers to persons who are neither engaged nor available to provide their labor.

There are two approaches of activity status by which the terms employed and unemployed can be used for the economically active population: the Usual Activity Status Approach and Current Activity Status Approach [4].

Usual Activity Status Approach- refers to all persons aged ten years over whether they were engaged in economic activities during most of the previous six months. Those who were engaged in productive activities during the reference period were classified as usually employed. Those who were not engaged in but available to be engaged during most of the six month prior to the survey date are considered as usually unemployed [4]. This approach is more appropriate for rural areas as it enables to capture seasonal variation of

\footnotetext{
1 The Ethiopia CSA defines urban areas as "localities with 2000 or more inhabitants" though in practice (i) all administrative capitals (regional, zonal and woreda capitals), (ii) localities with urban dweller's associations not included in (i) and (iii) all localities not included in either (i) or (ii) whose inhabitants are primarily engaged in non-agricultural activities are considered as urban.

2 For the purpose of measuring the economic activity status based on Ethiopian situation, the CSA UEUS (2012) fixed the lower age limit to ten years. This is because children in rural and urban areas are expected to engage at work in their early age such as collection of fire wood, looking after cattle, shoeshine, street vendor, petty trading...etc. Otherwise CSA collected the data from those persons aged five years and above.
}

activities.

Current Activity Status Approach- refers to all persons aged ten years and over whether they were engaged in productive activities at least for four hours during the seven days prior to the date of interview. The employed are those who were engaged in productive activity at least for four hours during the seven days prior to the date of interview; and those who had regular jobs or business or holdings to return to but who were temporally absent from work (i.e. those who were not at work or worked less than four hours) for various reasons such as illness or injury, holiday or vacation, strike or lockout, and seasonality of work, annual leave, temporarily closure of establishment. Unemployed population consists of persons, aged ten years and over, without work but available and ready to work if any job is found during the reference period of the coming one month (the survey week plus the subsequent three weeks). This is the completely relaxed unemployment definition of ILO $^{3}$ (unemployment measured based on the "without work" and "availability" criterion only) used by CSA UEUS [4] which is found to be convenient for urban areas.

In this essay the terms employed and unemployed and the data used are based on the current activity status approach and completely relaxed definition of ILO.

\subsection{Theoretical Explanations on Unemployment and Proposed Reduction Strategies}

Economists and development thinker have long been concerned with the unemployment problem in the world, particularly in developed nations, since the Great Depression (1930s) even before that and hence have formulated different theories to explain the problem and thereby draw policy implications for it. They had explained the phenomenon of unemployment and proposed its reduction strategies from different perspectives. Classical, Keynesian, Monetarist, Marxist and radical Marxist (Dependency) theories are among the major efforts in this respect.

The classical theory is essentially the laissez faire belief of pure capitalism. In this view, business cycles are natural processes of adjustment which do not require any action on the part of the government. Likewise, unemployment is caused by a deviation from the equilibrium prices and wages which would establish them with a free market [17]. The theory proposes that all markets equilibrate because of adjustments in prices and wages which are flexible. If, for instance, many people are unemployed, unemployment will then cause higher real wage to decline and thus firms can hire more workers, although at lower wage, and precisely reduces unemployment $[1,10,17]$. This prediction is reasoned by the classical argument that idle workers will bid down wage rate until cost of employment is such that employers will hire

\footnotetext{
3 In developing countries like Ethiopia, where the labor market is largely unorganized or of limited scope, where labor absorption is inadequate or where the labor force is largely self-employed; the standard definition with its emphasis on seeking work criteria might have had limited relevance, somewhat restrictive and might not fully capture the prevailing unemployment situation [4].
} 
more workers to the point where the equilibrium state is reached and full employment is attained. Full employment, however, does not mean that there is no unemployment. Still frictional unemployment and more of voluntary type does exist at the going real wage rate [17].

The classical theory suggests that involuntary unemployment is not the norm for an economic system because an adjustment in the wage rate will assure that the unemployed will be hired again. In addition, the need of workers to buy goods will encourage them to accept work at even the lower wage rates. Hence, if any unemployment exists, it is voluntary unemployment, only those who are reluctant to work for lower wages would then remain unemployed [1]. In general, classical theory of unemployment suggests that wage flexibility is the mechanism necessary to solve the unemployment problem, i.e. if wages are sufficiently flexible downward, then this decline can maintain full employment and will eliminate unemployment under a competitive economic system [17].

Unemployment reduction strategy proposed by classical economists (i.e. wage flexibility) seems inadequate for the developing countries as it offers little insight in to the realities of the unemployment problem in these nations. Firstly, in developing countries wage rate are normally (rules) not flexible downward as classical economists claims. This is because governments are major employers in many developing nations and wages are determined by a government (law) and workers are working under contracted wages so, firms cannot cut wages downward to increase employment as it is a violation of law and contracts $[1,10]$. Secondly, the majority of the populations in these nations are poor; and even if the governments need to apply wage repression policies, the decline in wage will lead to decrease in spending, productivity [17]; which all governments of these nations avoid as it leads to economic deterioration and delays the process of economic development. The wage cut can have also political consequences as it may lead to instability in the less developed countries [1].

Keynesian employment theory is built on a critique of the classical theory and it argues that prices and wages are not flexible as the classical theory asserts. Equilibrium may not exist in the product and labor markets and wages tend to be rigid on the down side because workers will not accept wages which do not permit them to live adequately and that periods of severe unemployment will occur (which the classical theory denied) [13, 27]. Moreover, as a consequence of workers negative reaction to lower wage Keynes believe that involuntary unemployment will occur. As the Keynesian theory was developed in the wake of the great depression, it was very hard to argue that only voluntary unemployment can exist as millions of workers were out of work [1, 13]. Keynes uses the term "full employment" to signify the absence of any involuntary unemployment and for him "full" employment rarely occurs, and the main immediate responsibility for the persistence of "'involuntary" unemployment lies with the persistence of interest rates at levels too high to induce employers to bid for all the labor available at the prevailing money rates of wages [27].

Keynesian theory's remedy to reduce such an involuntary unemployment is for a government to use expansionary fiscal or monetary policies. The application of one of these policies would reduce taxation; increase public spending and firms' demand for labor without affecting price and wage level (given that there is idle resources); and thus eliminating, or at least reduce the size of, the involuntary unemployment. Keynes further stated that, if unemployment exists, the any expansionary fiscal and monetary policy will lead to an increase in aggregate demand which then stimulate further production thereby more employment $[1,13]$.

According to the argument of some scholars it also seems less effective to apply the Keynesian remedy to unemployment problem of developing nations, though not totally be discarded. This is because of the reason that, economic structures of developing nations are not as flexible as the economic structure of developed countries- production cannot increase immediately to meet the demand conditions. Moreover, since supply of production cannot increase immediately, the rise in aggregate demand will lead to price level increase, inflation, and will create bottlenecks to the economy as opposed to a secondary impact on employment [1].

The monetary is another theory which assumes that firms and workers base their economic decision on real wages 4 and hence unemployment exists when firms and workers correctly perceive prices and real wages. The theory states that, workers are not willing to work in response to increase in their money wage if they see that there has no increase in their real wage. Similarly, firms are not willing to produce more output, and thus hire more workers, if their selling prices increase by the same rate as the cost of production. If selling prices increase faster than production costs, firms will speed up production and higher more workers $[1,11]$. The inadequacy of this theory for the unemployment problem of developing country is probably in that, unlike to the proposition of the theory, price are not perceived correctly by worker because of imperfect market thus the unwillingness to work or unemployment problem in a nation could not be related to inflation [1].

Marx's theory of capitalist development demonstrates the fact that capital-deepening or capitalist process of development leads to the proliferation of unemployment of labor. According to Marx, society's stock of labor can be absorbed if labor-intensive method of production is adopted, but a shift to a capital-intensive method of production will create huge unemployment [9]. Likewise, dependency theorists have focused on how foreign direct investments of multinational corporations distort developing nations' economies in general and employment opportunity in particular. In the view of these scholars, distortions include the crowding out of national firms and rising unemployment related to the use of capital- intensive

\footnotetext{
${ }^{4}$ Real wage is money wage adjusted for cost of inflation or wage regarded in terms of their purchasing power rather than as an actual sum of money.
} 
technology [9].

Overall, it can be said that unemployment in a particular era can be a combination of socio-economic and subjective individual factors. As illustrated in the above theoretical discussion, it could be caused by the socio-economic as well as by individuals forces. In all these factors, the most important thing is an individual's perception and behavior which may cause a situation of unemployment even in absence of any economical or societal constraints.

\section{Unemployment and Labor Market in Urban Ethiopia}

\subsection{Unemployment in Urban Ethiopia: Trends and Current Status}

In Ethiopia in the past times it was difficult to measure and study unemployment in general and urban unemployment in particular due to lack of reliable records. However, starting from 2003 the Ethiopian CSA launched serious of Urban Employment Unemployment Surveys (October 2003, April 2004, April 2006, May 2009, May 2010, March 2011 and March 2012), which are very helpful to make the study on urban unemployment. The last four surveys (the 2009, 2010, 2011, and 2012) have collected information from selected major towns with population size of 100,000 and above and including regional capital cities; and most of the discussions of this essay relay on these four year surveys, with high emphasis on the recent one (2012).

Periodic analysis of unemployment in urban areas of the country shows a declining trend in the four recent survey periods. The overall unemployment rate declined from 20.4 percent in May 2009 to 17.5 percent in March 2012 (Figure 1). Regarding sex, similar downward trend was observed during the four survey periods. However, the differentials of unemployment rate by sex for March 2012 show that female (24.2 percent) unemployment rate is more than two times as compared to male (11.4 percent) indicating the high prevalence of unemployment among females [4].

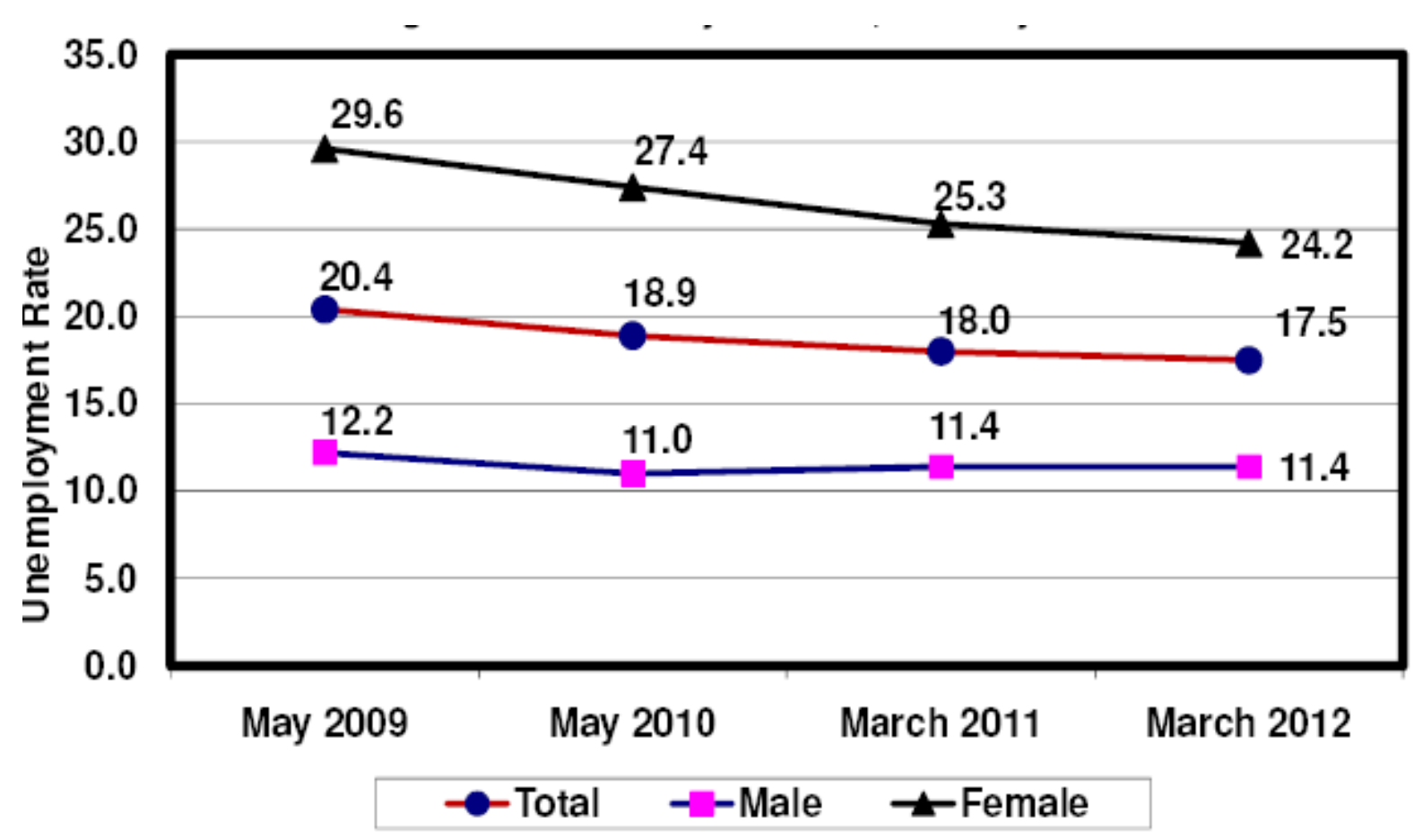

Source: CSA UEUS 2012

Figure 1. Trends of Urban Unemployment Rate by Sex, During the Four Survey Periods, Country Total 
The high unemployment rate among urban female in general and younger ones in particular reflects the economically marginalized position of females, who usually have heavy domestic work burdens and often little education. In urban Ethiopia as elsewhere in the nation household responsibilities and particularly child care are the major obstacles to females' labor market participation. A case in point, in this regard, can be the story of a young lady. She is a married woman having four children. She married while she was 18. The moment she gave birth to her first child she withdrew her learning at grade 11 , with a plan to continue in the coming year. However, as child caring and other domestic activities were found to be her major responsibilities, she failed to continue her education.

Urban unemployment in Ethiopia shows great difference across regional urban level. The March 2012 survey depicts that high unemployment rate is recorded in Addis Ababa City Administration (23.0 percent) followed by Dire Dawa Administration (22.7 percent); the lowest being 9.3 percent and 7.7 percent registered in Benishangul Gumuz and Gambella national regional states, respectively. The periodic analysis for the last survey years shows a declining trend in urban unemployment in Afar, Benishangul-Gumuz, Harari, Addis Ababa City Administration and Dire Dawa Administration while Tigray and Oromiya regional states show an increment in unemployment, which calls for further study[4].

The striking result is that the unemployment rate of literate persons (18.1 percent) is higher than the illiterate persons ${ }^{5}$ (15.2 percent) [4]. This could be related with the declining tendency that has been shown in the quality of education, despite improvement in school enrollment and number of graduates [20]. The other striking result is that among the literate group, the highest rate of unemployment nearly one-fourth is found for those who completed secondary education, grade ten ( 24.8 percent) [4]. The fact that those in the middle-spectrum of education takes highest share of unemployment should be one of the major issues that the government has to be concerned with which could signal to some extent the mismatch between the educational curriculum and the skills demanded in the labor market[12].

\subsection{Overview of Urban Labor Market in Ethiopia}

Each successive Population and Housing Census of Ethiopia demonstrates that national population size increased in significant proportions; from 39.9 million in 1984 to 53.1 million in 1994 and 73.9 in 2007, with an average annual growth rate of 2.4 percent between 1984 and 1994 and 2.6 percent between 1994 and 2007 [5]. Regarding urban population the census result revealed that it has increased from 14 percent in 1994 to 16 percent in 2007 . The total urban population of the country is estimated to be

\footnotetext{
5 Those who did not attained either formal non formal

schooling an so cannot read and write
}

14,011,269 as of March 2012[4]. One of the effects of such large urban population is increment in the size of the labor force. Out of the total urban population of the nation 11 , 110,653 are populations aged ten years and above, of which the total labor force (economically active population) as measured using current activity status approach is 6,944,691(62.5percent) [4]. Having such a huge number of urban labor forces it is good to have a look on the urban labor market situation in order to evaluate the labor force utilization. This section, therefore, tries to give an overview about the labor market in urban Ethiopia.

In order to satisfy the ever-increasing demands of governments and the social partners (workers' and employers' organization) for timely, accurate and accessible information on the world's labor markets and to facilitate the comparison of the key elements of national labor markets, in 1999 the ILO launched programme on Key Indicators of the Labor Market (KILM) ${ }^{6}$. Based on available data, only seven key indicators of the labor market are considered feasible for Ethiopia [16]. These selected seven $\mathrm{KILM}^{7}$ can provide a better insight on the labor market situation in the country. Accordingly, in this section of the essay the urban labor market situation of the country is described from the point of view of these seven KILM.

Labor force participation rate measures the extent of economically active population in the working-age population $^{8}$. The labor force participation rate in urban Ethiopia is 62.5 percent, which means out of 100 persons of the working age, almost 63 persons are engaged in or available for productive/economic activities, while the remaining are inactive (neither engaged nor available for work) [4]. In urban Ethiopia the inactivity rate, which measures the proportion of the working-age population that is not in the labor force, is 37.5 percent. One possible explanation for inactivity could be the improved educational condition of the nation (huge number of students) which in fact could be seen as positive aspect as far as the social status of the population is concerned. However, unless job creation goes at equal pace with this huge skilled/educated labor force which is expected to join the labor market, massive urban unemployment is inevitable in the future.

Inactivity could also be linked with the health status of individuals. Being ill-health one could neither be engaged nor available for productive work. Hence, the lagging behind in improvement of the health sector in the country could be one of the contributing factors for inactivity. From the total inactive population, the great proportion is for females, accounting 62.2 percent, while males account 37.8 percent [4]. The very basic reason for this high proportion of inactivity of female could be the fact that most female are engaged in unpaid household chores such as preparing food,

\footnotetext{
${ }^{6}$ Summary of the 18 ILO Key Indicators of the Labor Market are given in Box 1, in Appendix I.

Labor force participation rate; Employment-to-population ratio; Employment by sector; Employment in the informal economy; Unemployment rate; Youth unemployment and Inactivity

Working-age population refers to population aged ten years and above (CSA UEUS 2012)
} 
cleaning the house, taking care of children which are not considered as economic activity. A case in point is the account given by 45 years old married informant. Her husband is employed in one private company in Akaki area, Addis Ababa. The household has 11 members. The main source of income for the household is the monthly salary of her husband. The informant was also working in private company, but she was fired by the owner due to personal conflict with him. It has been more than 10 years since she stopped working. Soon she lost her job she did not resort to other form of livelihood rather she preferred to engage in taking care of her children and her family. She reported that she has a lot to work in her home- cooking food, washing clothes, to look after her children.

Employment-to-Population ratio is the other KILM in Ethiopia which measures the percentage of employed persons in the population. It provides information on the ability of an economy to create employment [16]. The 2012 survey result showed that 51.5 percent of the urban working-age population at national level is employed [4]. This means that about 48 percent of the Ethiopian urban working-age population is not engaged in productive activities due to unemployment or being inactive. Moreover, the differentials of employment-to-population ratio by sex illustrate that 61.7 percent of male and 42.6 percent of female were employed during the survey time [4]. The lower figure of employment of female could reflect one or more of the following factors. Women tend to leave their work or being unemployed to give birth and raise children. Women are also often responsible for various tasks at home, which can hinder them from seeking paid employment. There could be also a tendency to undercount women who do not consider their work as employment or are not perceived by others as working.

Employment by sector, being the other KILM, disaggregates employment into three broad sectors agriculture, industry and services which are taken as percentages of total employment. Sectoral information is particularly useful in identifying broad shifts in employment and stages of development of a country [16]. Looking at Ethiopia's urban employed population by major sector divisions, most employed population are engaged in the service sectors which absorb 71.3 percent, while industry and agriculture share 20.5 and 8.2 percent respectively of the total urban employed population [4]. In fact this data cannot be a good indicator of the level of development of Ethiopia as it only shows labor market of urban areas, rather than the country's total.

Employment in the informal sector is another KILM which relates the estimated number of persons employed in the informal sector to the total number of employed persons. The survey result reveals that out of the total urban employed population 31.7 percent were engaged in the informal sectors ${ }^{9}$ [4]. From this it is possible to say that informal

\footnotetext{
9 According to CSA UEUS (2012), employee in the informal sector refers to all persons who, during the reference time, were employed in a business/enterprise having no book of account that show the monthly
}

sector in urban Ethiopia is an important part of economic life which tends to absorb a considerable amount of the growing urban labor force. Given the inadequate job opportunity and high competition of job market in urban Ethiopia, dwellers have to look for a livelihood, and hence involving in informal sectors have become the only existing opportunity for some. As such when people are unable to obtain formal employment, many people are observed coping through a variety of informal activities, among others is self-created jobs.

The survey also shows that, the proportion of female who works in the informal sector (42.2 percent) is found to be higher than that of their male counterpart (24.2 percent) [4]. This data could provide a clear idea about the socio-economic contribution of informal sector for females. This is because, self employment which is the dominant aspect of the informal activity in most urban areas of the nation is an important source of livelihood for females and their families, particularly for those who cannot undertake regular work far from their home. A woman informant, who is one of the many exemplifying the situation of female who support their living through self-created job, would substantiate the case in point. The woman lived with her husband for about five years, and it has now been around eight years since she got divorce to him. From that time on she is living with her two daughters. The very basic reason for their divorce was that her husband was not willing to support their living. Thus, she has to engage in different activities. Earlier she was employed as a daily laborer, and then she got employment in private organization though it was not long lasting. Soon she resign her job from the private organization she has to look for livelihood as she have to pay for school fee of her children and cover all their living expenses. Hence, she engaged in self-created jobs such as vending straw (as pasture for donkey and horse), grass used for decoration of coffee ceremony and other commodities like onion. Her monthly income from such activities ranges from 300 to 600 Ethiopian Birr which is in fact inadequate to fulfill their needs.

A look at this story, as it could also be the case for most other urban dwellers, depicts that informal sector is found as a better way out to the socio-economic problems and is a mechanism of coping during hard times. However, despite the fact that informal sectors are essential in ensuring livelihood and providing the means of survival for most, their contribution to satisfactory work opportunities is highly questionable. This is because most of the informal sectors lack institutional protection; have very low level of productivity and income; tend to have little or no access to organized markets, to credit institutions, to modern technology, to formal training and to many public services.

The other KILM are unemployment indicators which include unemployment rate, youth unemployment and inactivity. The unemployment rate which is one of the core

income statement and balance sheet and no business/enterprise license. And persons employed in business that satisfies at least one of these two conditions is considered as working in the formal sector. 
indicators of the labor market is discussed in detail in section 3.1. The KILM information on youth unemployment is usually given by youth unemployment rate which expresses youth unemployment as a percentage of the youth labor force [16]. In Ethiopia youth are more vulnerable to the problem of unemployment than any other group of the population particularly in urban areas. The statistical data shows that urban youth unemployment rate in the country is 23.3 percent; the figure being greater for female youths, 29.6 percent, as compared to males, 16.4 percent [4].

The high prevalence of youth unemployment rate in urban Ethiopia could be attributed to different factors. One possible factor could be the rural-urban migration of youth. In rural part of the country, where there does not seems to have surplus labor in agricultural sector, most of the labor force is underemployed or engaged in productive work only for a defined period in a year which encourages migration to urban areas anticipating better job and wage, and yet remain jobless. Furthermore, the high population growth rate of the past decades has generated a large share of children (0-14 years) and youth (15-29) that account 32.1 percent and 36.2 percent of the total urban population in 2012, respectively [4]. These figures suggest that, the population in the youth age group continue to grow because of the young dominated demographic profile; thereby in the future more youth will join the labor force which could leave the current issue of youth employment open.

The prevalence of unemployment among youth could also be due to employers' perception that young particularly female employees have low skill and little or no work experience and hence could not produce enough. In the statement of 24 years young female informant the reason for her joblessness is the lack of startup finance, but above all it is employers' perception that challenges she a lot. Most employers assume that she can not to fit with the available job. Such stereotyping of youth group in general and female ones in particular could expose them to high degree of unemployment.

The other possible factor could be the mismatch between employment creation and the growth of the young labor force. The rural-urban migration coupled with the natural population growth of the urban area is increasing the young labor force of urban areas. However, employment generation is not growing at equal pace with the labor force; a case in point could be the inadequacy in employment opportunities that can absorb the fast increase of the number of university and technical school graduates. Such huge skilled labor force is then forced to stay longer without job, being dependent on their family. The rising number of young labor force entering the urban labor market each year demands further job creation to benefit the economy out of it. In fact as recent finding shows the problem is compounded by a lower quality of education and skill mismatches thus it calls for specific interventions such as undertaking regular labor market surveys with the objective of assisting universities and technical schools to align their education and training programs to the skill needs of the labor market [12].

\subsection{Efforts in Solving Urban Unemployment in Ethiopia}

Despite the high rate of unemployment and the sluggish pace of job creation in urban Ethiopia, efforts to reduce urban unemployment are varied. The efforts could be viewed from two dimensions: (i) creating productive and remunerative jobs for various skill categories as per the requirement of the economy (demand side) and (ii) enhancing the skill levels of available labor force to match it with the skill that the economy requires (supply side). In Ethiopia, in the supply side a comprehensive strategy of employment creation seeks to promote job creation in the public sector, in the private sector, and also in terms of promoting self-employment and entrepreneurship in urban and peri-urban areas [20].

Public sector is a major formal sector employer in urban Ethiopia. It accounts for almost two-thirds of formal sector employment [20]. In public sectors urban unemployment reduction efforts are being done through the development of urban centers as production and service areas and investment in labor-intensive infrastructure development. Public investment in social sectors (education and health) could contribute to employment opportunities by building up infrastructure. The recent rapid expansion of government schools, colleges, universities, clinics and hospitals is creating urban employment opportunity.

In a country like Ethiopia where there is a huge labor force and unemployment persists, particularly in urban areas, it is clear that a labor-intensive approach would create huge job opportunities from a given amount of investment. In this regard employment generation through urban infrastructural development program and the construction sector, as indicated in the Growth and Transformation Plan (GTP) of the country can serve as an indication of the effort of the government of Ethiopia towards the reduction of urban unemployment problem through labor-based approaches. A classic example can be Integrated Housing Development Program (IHDP), an innovative program designed with the aim of addressing urban housing problem while generating employment. Such program like IHDP as it requires large number of people with varied qualification can greatly contribute for urban unemployment reduction. Other instance could be Cobblestone paving - a labor intensive initiative that creates substantial job opportunities in different activities such as quarrying, chiseling, transporting and paving. It creates job opportunities for about 489,000 unemployed citizens in different urban areas of the country. It has also given a chance to establish a lot of Micro- and Small- Enterprises (MSEs) on manufacturing and other construction sectors [18].

Accelerating private sector development is another important entry point to enhance opportunities for job creation in urban areas. In recent years there has been a promising start in private sector investment and business activities (eg. floriculture) with their associated employment opportunities. The country's National Employment Policy and Strategy identified areas where particular focus and 
interventions are required to create conducive business environment to enable the private sectors to render employment opportunities which include improving access to business land, enhancing access to credit, improving infrastructure services, and providing special incentives like subsidized credit services, preferential land lease, reducing tax rates, and effective training services for priority sectors [20] .

Today, there have been such attempts in improving the legal and administrative framework in urban areas. A good example is the promotion of Micro and Small Enterprises (MSEs) and supporting them with working place/land/, finance/credit/ and training which is high on the agenda of the Ethiopian government in terms of its policy framework for private sector development. The government of Ethiopia has formulated a National MSEs Development and Promotion Strategy in 1997, which enlightens an approach to alleviate the problems and create enabling environment to the growth of MSEs. To this effect, in 2011/12 to alleviate the financial constraints of the enterprises, over 1 billion Birr was provided in credit to various MSEs; training was provided to 931,907operators on entrepreneurship, business management and technical skills; and 5000 hectares of land, 1,757 shades and 46 blocks were distributed to MSEs in all cities of the country, which has helped to enhance employment opportunity and reduce urban unemployment [15]. Here the remedy of Keynesian theory to reduce unemployment i.e. for a government to use expansionary fiscal or monetary policies which promote investment activities and enhance firm's demand for labor seems to be relevant to Ethiopia's context.

However, regarding the provision of credit and the follow up activities all the informants of this study reported as there is flaw in the provision of credit and institutional weakness in management and follow-up activities. They complained that the credit provision system should not be only for those who organized themselves in group; people should have to have access to credit at individual level. An interesting interview finding in this regard is the account of a young (29 years old), male informant. Because they, he and his friends, lack employment, they planned to engage in production of bricks, being organized in micro enterprise. However, they failed to be successful as some of the members were reluctant to work, and they wanted the money, the startup capital they were given from the government, for their own personal purpose. Their failure is also attributed to lack of supportive services (like water and electricity) from the government. The informant further stated that if they were allowed to have access to credit on individual base we would be responsible and could perform better. He complained that working in group is difficult, and thus what is better is for the government to provide credit (startup capital) at individual level.

In urban areas of the country employment in private sector is also being enhanced by promoting labor-intensive businesses and investments through relatively less costly method of leasing land. These days foreign construction companies which usually rely on capital intensive activities and experts brought from their own countries (e.g. Chinese companies) are now becoming labor intensive, and thus contribute to urban unemployment reduction. In this regards the Marxist and dependency theories which states society's stock of labor can be absorbed if labor-intensive method of production is adopted seems to have some relevance. With a shift from capital-intensive to labor-intensive activities/investments more available labor force could be absorbed.

In a situation where unemployment problem is high, promoting self-employment forms an integral part of any intervention aimed at reducing unemployment. In urban Ethiopia there are also few attempts to promote individuals for entrepreneurship (eg. provision of entrepreneurial educational programs at tertiary level) and for self employment through training and credit availability though the actual employment gains via such approaches have not been that much satisfactory. This could be due to the lack of environment that encourages risk taking and market development [8].

The second dimension in the effort of urban unemployment reduction is the supply side which targets on enhancing the skill levels of available labor force to match it with the skill that the economy requires. Basically, it is concerned with improving and raising labor productivity, which can be achieved mainly through education and training. These days the government of Ethiopia is striving to enhance the skill of the labor force through the expansion of education and training. For example, through the implementation of Technical and Vocational Education and Training (TVET) strategy- training, business counseling and technology transfer- the government focuses on producing adequate supply of middle level skilled human resources demanded by the industry and MSEs. Up on the completion of grade ten those who do not score well enough in the national exam to continue in preparatory school (grade 11 and 12) have the opportunity to pursue formal TVET. It has also been given special emphasis due to the belief that encouraging and equipping the labor force, particularly the youth, through a strong skill-based training program to become self-employed is an important way to reduce youth unemployment.

\subsection{Challenges of Employment Creation in Urban Ethiopia}

Though improvements exist in unemployment reduction in urban areas of the country, the labor market situation particularly the demand side remained somewhat stable. The data shows a largely unchanged urban labor market situation between 2009 and 2012. Urban labor force participation rate and employment rate do not show that much improvement. As the statistical findings indicate urban labor force participation shows less increment from 59.7 percent in 2009 to 62.5 percent in 2012. The size of urban employed population also shows small improvement from 47.5 percent 
in 2009 to 51.5 percent in 2012 [4]. Yet about 48 percent of the Ethiopian urban working-age population is not engaged in productive activities which suggest that despite a relative improvement in urban unemployment reduction, urban sectors have not yet become able to afford adequate job. This could imply the presence of some factors that account for the sluggish pace in the growth of the demand side of the labor market, in both public and private sectors.

Accounting for almost one fifth of urban workers and for about 68 percent of employment among those with higher education, the public sector has a major influence on urban labor markets of Ethiopia [26]. However, cut backs in public expenditure and privatization of public enterprises have tended to reduce the employment creation role of the public sector [20]. Since private sector is the engine of industrial growth, the government of Ethiopia has been supporting the privatization program to enhance the contribution of private sectors to economic growth and industrialization of the country. On the other hand, privatization is always associated with the reduction of redundant labor, resulting in an increase in unemployment. In Ethiopia, half of all industrial establishments were state-owned, and these establishments were quite large and employed over 90 percent of all industrial employees [22]. Yet, privatization of industrial establishments is a reform that affects nearly everyone in the industrial sector. Moreover, the shutdown of some other industries with the intention of privatization also leads to massive involuntary unemployment. Though not as such a unique case, the story by a 38 years old male informant exemplify this fact. Informant's father was working in Akaki textile factory from which his father gain earning and support his family. The factory was one of the huge state-owned industry which absorbed about 8000 employees, both permanent and temporary. With the aim of privatizing the industry the state closed it firing this huge labor force. The measure was so severe that many including the informant's family faced difficulty of sustaining life. The most surprising thing with this factory is that it has been more than 20 years since it has been closed and even now it is not functional. The message that can be drawn from this story is that employment effects of privatization should have been given due consideration by the government when deciding upon the strategy of privatization.

Likewise, the formal private sector has not yet made a major contribution to job creation in urban Ethiopia; and various barriers have affected its dynamism as a source of jobs such as tax rate, lack of or inadequate finance and inadequate infrastructure. Tax rate is one of the most serious obstacles to the expansion of firms and thereby employment. Firms in Ethiopia agreed with the statement "I don't want my business to grow too much because then I will have to pay huge taxes" [26]. This suggests that taxation could indeed play a role in the decision of some firms not to formalize and expand, which could negatively affect urban unemployment reduction. Moreover, although Ethiopian government recognized the role of unemployment reduction via the expansion of MSEs and is trying to create enabling environment for their expansion, these efforts are not only inadequate but also fragmentary/uncoordinated and thus it has been a challenge for individuals to engage in such enterprises and sustain their work. The experience of one young male informant could be an instance in this respect:

$\mathrm{He}$ is a 27 years old young person born in Akaki area of Addis Ababa. He has completed grade 10. As he did not score satisfactory result, he could not get the opportunity to pursue preparatory schooling or TVET. So, he has to find a living to cover his expenses and support his family. The moment he knew as he could not pursue his learning he discussed with his friends and decided to engage in car wash activity. Although they were hopeful in having their own business and be successful in their future life, things were not found to be easy. At the beginning they requested the concerned body to give them working place and startup finance, in the form of credit. However, as they were bored with the bureaucracy, they started the business with their own finance. Yet they could not sustain the business as they were unable to afford the tax, rental, high water and electricity tariffs. Now being disappointed, they all are drug abused; and from that time on the informant stated as he had decided to engage in any activates, be it a crime, as he have to fulfill his need.

In general, although the policy and strategy clearly stipulates the provision of support, the above story in fact explicitly capture the institutional weakness in supporting individuals and MSEs.

\section{Concluding Remarks and Policy Implications}

The phenomenon of unemployment is one of the major social problems of most urban centers of Ethiopia. The high rate and the prevalence of the problem require a timely measure. Research as a major tool for indicating appropriate action, policy development and program execution or intervention has to be given priority. It is with this objective that this study is conducted.

Although recent trends suggest as Ethiopia's economy showed improved performance including reduction in unemployment; urban areas of the nation are still characterized by high unemployment and for majority duration of stay without job is relatively long. There is heterogeneity in the performance of different groups with female and youth groups facing the greater challenges. Female are especially disadvantaged in the labor market and typically face worse outcomes with higher levels of unemployment and a greater concentration in the informal sector. The finding suggests that policies need to address the poor labor market conditions for female as well as implement labor-intensive employment creation strategies which benefit the rising number of educated youth entering the labor market.

Recognizing the role of MSEs in unemployment reduction the government of Ethiopia has launched extensive program 
of promoting and supporting MSEs. However, given the high unemployment rate in urban areas and despite the clear stipulation of the provision of support in policy and strategy these efforts are not only inadequate but also fragmentary/uncoordinated compounded by institutional weakness and thus it has been a challenge for individuals to engage in such enterprises and sustain their work. Thus, much has to be done in the area of MSEs and other labor intensive activities.

It was found out that the informal sectors with their labor intensive technology absorb a considerable amount of the growing urban labor force of the nation, particularly of female labor force. However, their contribution to satisfactory and sustainable work opportunities is highly questionable. Hence, to benefit a lot from these sectors in terms of unemployment reduction and thereby to improve the livelihood of urban community; and in order to make informal sector partners to the formal sector and eventually help them graduate to the formal sector, the government should provide institutional protection; arrange access to organized markets, to credit institutions, to modern technology, to formal training and to many other public services.

The government of Ethiopia has been supporting the privatization program to enhance the contribution of private sectors to economic growth and industrialization of the country. However, as privatization is always associated with the reduction of redundant labor, employment effects of privatization should have to be given due consideration by the government when deciding upon the strategy of privatization.

The interview result though it could not be conclusive gives some indications that the current credit provision system which demands people to organize and work in groups were found to be disappointing, in many cases. It is therefore important to undertake some further detailed studies and discussions on the effectiveness of the current credit provision system and on how the government should redesign and modify the existing credit system so that credit can be accessed at individual level for those who wish to set up their own income generating projects, where people face difficulties to organize and work in group.

\section{Acknowledgement}

I owe my sincere gratitude to all of the authors of the materials that I have reviewed as well as individuals and offices who provided the necessary data for this study.

\section{REFERENCES}

[1] A.S. Bin-Obaid. Classical, Keynesian and Monetarist Theories of Unemployment: Are they Adequate to LDCs? Journal of Economics and Administrative Sciences. VOL. 13 pp. 151-172, 1997.

[2] A. G. Blomqvist. Urban Job Creation and Unemployment in LDCs: Todaro Vs. Harris and Todaro. Workshop Paper, 2012.

[3] N.H. Broussard and Tsegay Gebrekidan. Youth Unemployment: Ethiopia Country Study International Growth Center, Working Paper 12, 2012.

[4] Central Statistical Authority (CSA). The Federal Democratic Republic of Ethiopia, Central Statistical Agency. Analytical Report on the 2012 Urban Employment Unemployment Survey. Statistical Bulletin. Addis Ababa, Ethiopia, 2012.

[5] Central Statistical Authority (CSA). Summary of Statistical Report of the 2007 Population and Housing Census. Addis Ababa, Ethiopia, 2008.

[6] Economic Commission for Africa (ECA). Economic Report on Africa 2005 Meeting the Challenges of Unemployment and Poverty in Africa. ECA Publication Cluster, 2005.

[7] Getinet Astatike. The incidence of youth unemployment in urban Ethiopia. a paper presented at the 2nd EAF International Symposium on Contemporary Development Issues in Ethiopia, 11-13 Jul 2003, Addis Ababa, Ethiopia, 2003.

[8] Getinet Astatike. Determinants of self-employment in urban Ethiopia: Panel data based evidence. Paper presented at the 3rd International Conference on the Ethiopian Economy held in Addis Ababa, 2004.

[9] B.N. Ghosh. Dependency Theory: Revisited. Aldershot: Ashgate, 2001.

[10] F. C. Holte. Four Papers on Unemployment. Central Bureau of Statistics of Norway. Oslow, Kongsvinger, 1988.

[11] E. Malinvaud. The Theory of Unemployment Reconsidered. 2nd ed. Oxford: Basil Blackwell Ltd, 1985.

[12] Martha Kibru. Employment Challenges in Ethiopia. Addis Ababa University, Ethiopia, 2012.

[13] N. Meccheri. Wage Behavior and Unemployment in Keynes's and New Keynesians' Views. A Comparison. Revised version. Dipartimento di Scienze Economiche, Facolt’a di Economia, Universit’a di Pisa. Via C. Ridolfi 10, I-56124 Pisa, Italy, 2005.

[14] Mesfin Mulu. Determinants of Women Unemployment in Ethiopia: A Multilevel Model Approach.Masters Thesis. Addis Ababa University, Addis Ababa, Ethiopia, 2012.

[15] MoFED. Annual Progress Report for Fiscal Year 2011/12. Growth and Transformation Plan. Ministry of Finance and Economic Development. Addis Ababa, Ethiopia, 2013.

[16] MOLSA. Labor Market Dynamics in Ethiopia: Analysis of Seven Key Indicators of the Labor Market (KILM). The Federal Democratic Republic of Ethiopia Ministry of Labor and Social Affairs Addis Ababa, Ethiopia, 2013.

[17] A. H. Mouhammed Important Theories of Unemployment and Public Policies. Journal of Applied Business and Economics vol. 12(5), 2011.

[18] Ministry of Urban Development and Construction (MUDC). Cobblestone- Youth Job Creation Initiative: The Ethiopian Experience. UN-Habitat 2013, Scroll of Honor Award 
Competition Proposal, 2013.

[19] F.Nazir, M.A. Cheema, M.I.Zafar and Z. Batool. Socio-Econoic Impacts of Unemployment in Urban Faisalabad, Pakistan Journal of Socila Science, 18(3): 183-188. Department of Rural Sociology, University of Agriculture, Faisalabad 38040, Pakistan, 2009.

[20] National Employment Policy and Strategy (NEPS). National Employment Policy and Strategy of Ethiopia. Addis Ababa, Ethiopia, 2009.

[21] B. Paul. Urban Unemployment in Developing Countries. Geneva: ILO, 2005.

[22] Solomon Deneke. Private Sector Development in Ethiopia. International Conference on African Development Archives. Paper 19, 2001.

[23] P. Serneels. The Nature of Unemployment in Ethiopia. CSAE
WPS/2004-01, 2004.

[24] A. Syson. Causes of Increasing Rate of Urban Unemployment Among the Youth the case study of Lubaga Division in Kampala District in Central Uganda. Between the ages of 14-35 years. A Research Report, Makerere University, 2011.

[25] Tegegn Gebeyaw. Socio-Demographic Determinants of Urban Unemployment: The Case of Addis Ababa. Ethiopian Journal of Development Research Vol.33, No.2, 2012.

[26] World Bank. ETHIOPIA Urban Labor Markets in Ethiopia: Challenges and Prospects. Volume I: Synthesis Report Poverty Reduction and Economic Management Unit Africa (Region), 2007.

[27] J. Viner. Review: Mr. Keynes on the Causes of Unemployment. Oxford Journals. Oxford University Press in collaboration with JSTOR, 2011. 